\title{
イネ科花粉症における特異的減感作 治療の遠隔成績
}

\author{
金関 延幸・高橋 光明 - 海野 德二: \\ 矢舆 洋*
}

Specific Hyposensitization in Graminea Pollinosis

\author{
Nobuyuki Kanaseki, Mitsuaki Takahashi and Tokuji Unno \\ (Asahikawa Medical School) \\ Hiroshi Yajima \\ (Shizuoka Saiseikai Hospital)
}

The long-term results of hyposensitization were examined in 114 patients with Graminea pollinosis. All 114 patien ts had positive reaction to Graminea antigen and nasal allergic symptoms during the Graminea pollen season. The effective rate of specific hyposensitization with Graminea pollen extracts was from $65 \%$ to $85 \%$, (mean, $75 \%$ ) and was influenced by sex and the period of disease.

Key words: specific hyposensitization, graminea pollinosis, long term result

\section{はじめに}

イネ科花粉は北海道における花粉粒:の 主要抗原で 6 月から 9 月にかけて飛敬し，ての 期間には本州におけるスギ花粉症:56) に勝る之 屯少らない激しい症状を来たす。我々は㺟和152 作 6 月から，喼和60年 9 月までに，当科アレル ギー外来を受診したイネ科花粉症患者症例にイ 亦科花粉抗原による特異的減感作治療を施行 し, その遠隔成績について, 調查, 検微したの で報告する。

\section{対象および方法}

対象はイネ科花粉症之確定彰断し特異的減感 作療法を施行した症例で一作以上:徼察し得えた 114例である。男女比は男52例, 少62例で平均
年餋25才であった（図 1 ).

全例，イネ科花粉抗原（鳥居製，チモシーま たはカモガヤ）の皮内反応が陽性で, 花粉飛敞 時期に症状を有する症例であった。

114 例中 63 例はイネ科学独感作例で他の51例 は重複感作例（HD19例，ダ二 5 例，アルテ八 ナリア 1 例, 白權19例, エゾョモギ 8 例, ハン ノキ 1 例）であった，

RAST 検查は70例に施行し score 2 以上陽 性率はカモガヤで $92 \%$, チモシーで93\%であっ た。

特異的減感作:䝤法は舁居製診断用のチモシー またはカモガヤ抗原エキスを使用した。方法は 花粉飛散の終了後より開始し, 皮内反応陽性の 


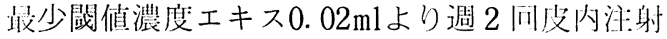

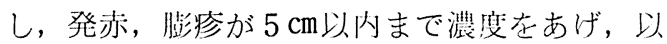
後は維持療法とした。維持療法は备週，2週年:

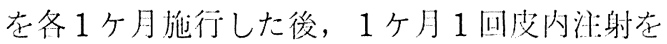
䋛続した。花粉飛腊期間は原剘として減感作在 归した。飛攼終了後 2 件目以降は $1 \sim 3$ ケ月 伯に 1 回注射圭行なった。

效果判定の調植は例作花粉の飛怔し为状の出 垷する6月初们から 7 月中们の間に行なった (应 2 ). 効果の判定は奥田の判定基淮?)によ
り行ない改渔以に:在有効とした。

また，効果のけ覚的評価をアンケート淍查で 行った。調查時再米しなかった症例存含め現在: まで特晎的減感作療法在施行した 139 症例に諴 枯期間内に質間あるいはアンケート用紙老郵送 して回签を得た。

\section{結 果}

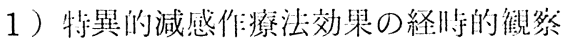
特異的減感作療法の総合効果老経作的に観然 した（図 3 )。減感作 1 年目の有效染は $65 \%$

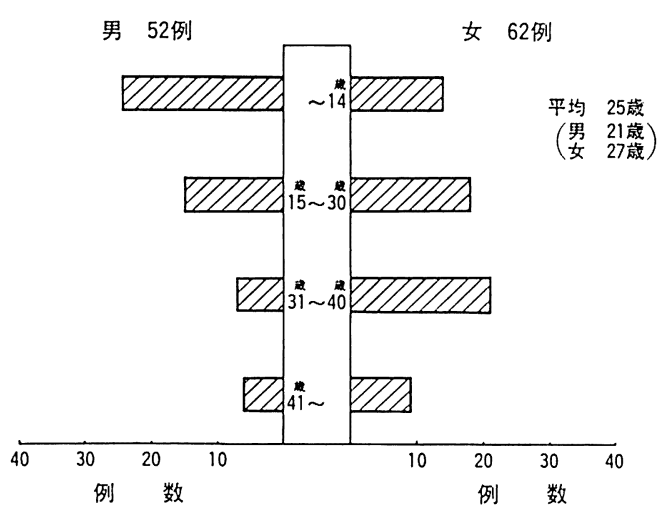

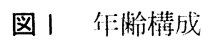

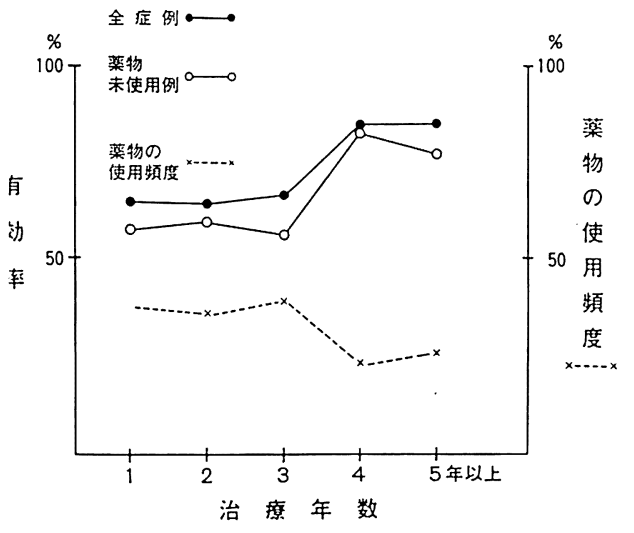

図 3 減感作治獠：総合効果

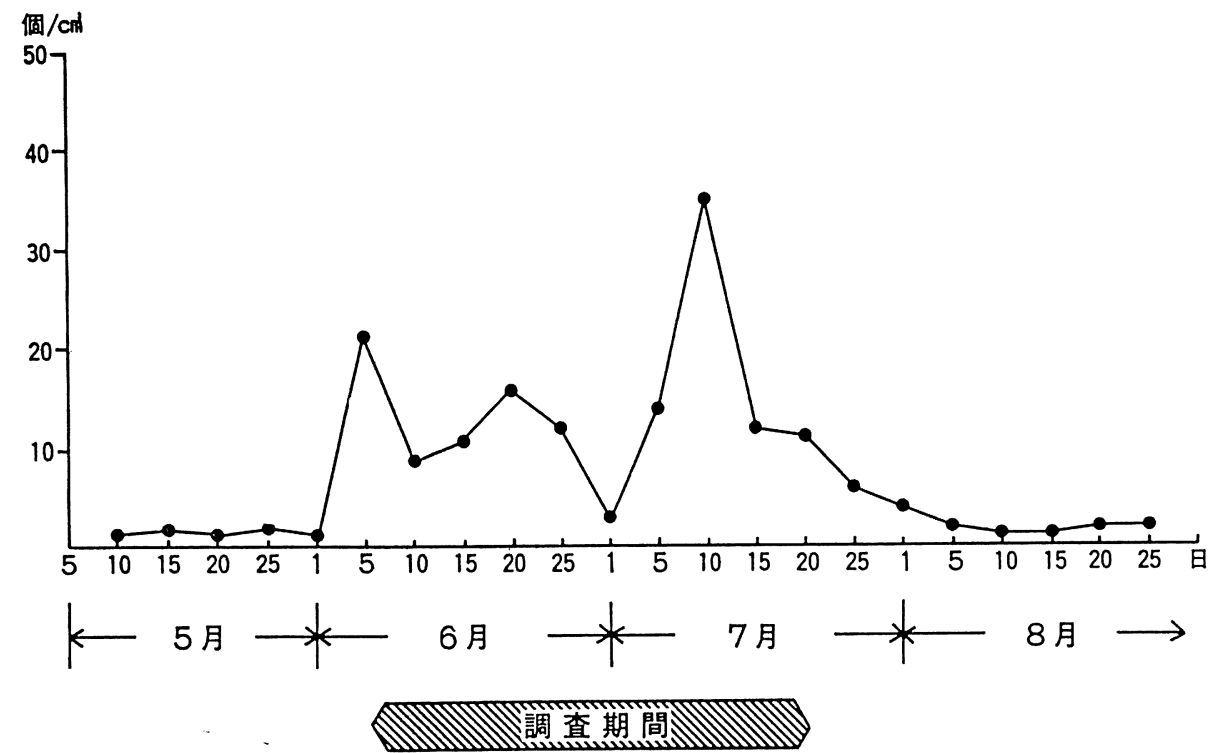

図 2 空中飛散花粉数及び調查期間 
（74例/114例）で 2 年目は64\%（47例/74例）

3 年目では67\%（33例/49例）になり 4 年以上 では85\%（24例/28例）に上昇する傾向にあっ た.

効果判定封すでに薬物を使用している症例が ありその頻度は約 $35 \%$ で治療年数が長い人ほよ゙ 使用頻度は低下していた。

2 ）減感作治療に及胫す因子

減感作治療に影樂する因子を検討するため K，(i)男女別，(ii)年齢別，(iii)総 IgE 值別，(iV) 重複減感作別，(V)篗病期間别のそれぞれについ て，有效率を調査した。

(i)男女別有効率では，女性:のうがやや高く治 療年数 3 作目で, 推計学的に有意差が認められ

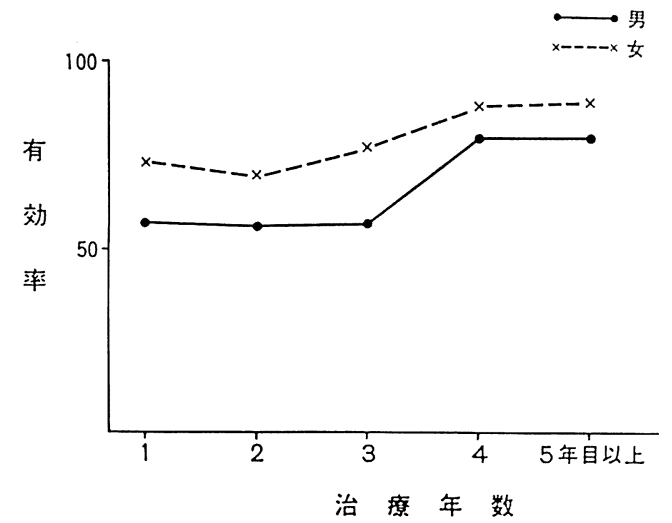

図 4 男女別有効染

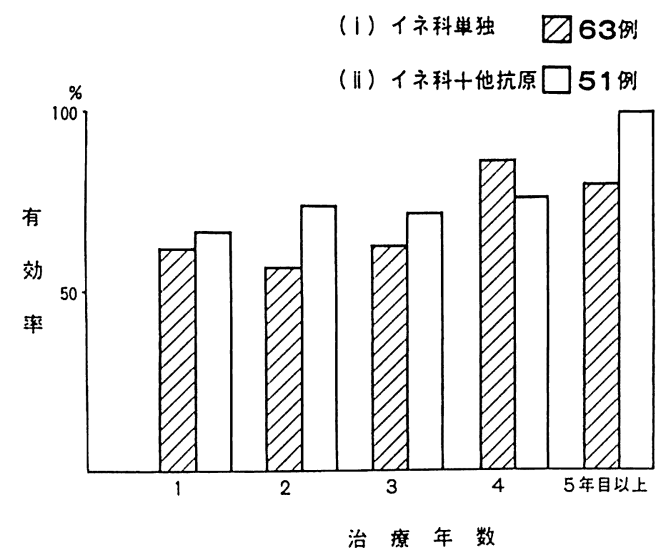

図 6 重複減感作の有無による効果
た $(\mathrm{P}<0.05)$ (図 4$)$.

(ii)年齢別について，減感作 1 年目の有効率を みると, 約 $58 \%$ \% $68 \%$ で, 各年龄層で推計学的 に有意差はなかった。

(iii)総 $\operatorname{IgE}$ 值別では，400U/ml未湍と400U/ $\mathrm{ml}$ 以上の 2 群に分けてみると, 減感作 2 年目, 3 年目の IgE 高值例に有効褔が高かったが, 推計学的に有意差はなかった（図 5 ).

(iV)重複減感作別では, 治療年数 4 年目を除 き, 各年数共, 重複減感作群の方が単独減感作 群より有効率が高かったが，推計学的に有意差: はなかった（図6).

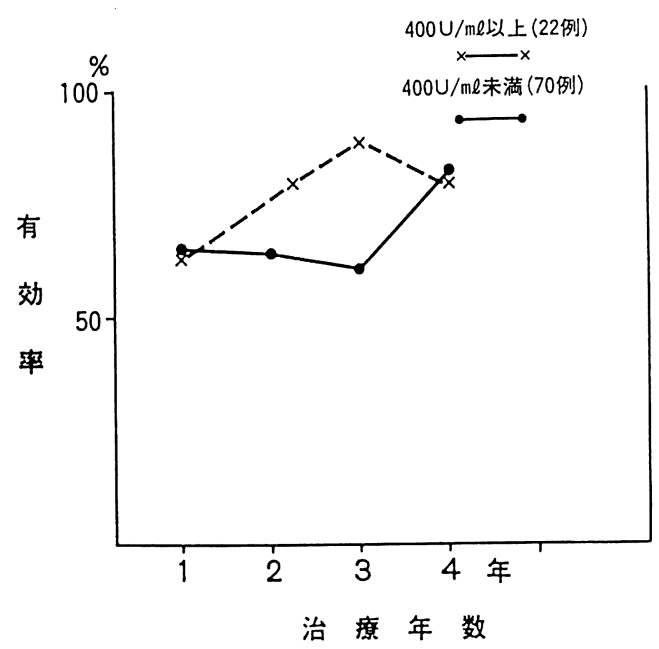

図 5 Total IgE と総合効果

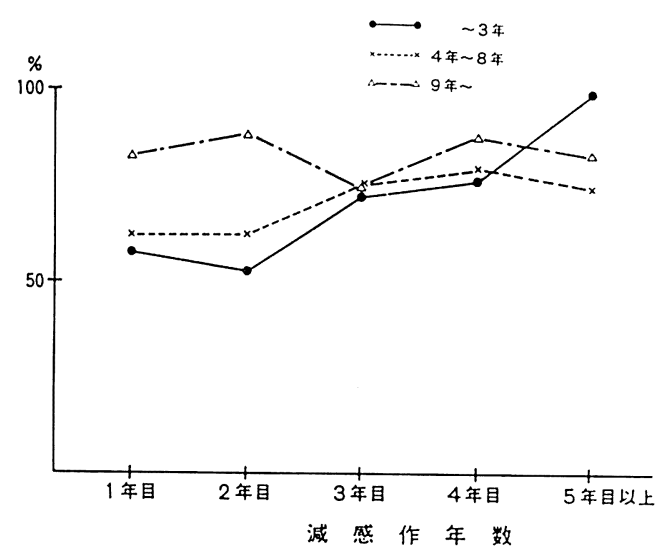

図 7 䍜病期間別効果 
(V)䍜病期間を 3 年以下， 4 年〜 8 年， 9 年以 上の 3 群に分けて有効率を見た。減感作 2 年目 で， 9 年以上の群が他の群より危除率 $5 \%$ 以下 で有意に高かった（図 7 ).

3 ）鼻アレルギーの 3 症:状の改善率（図 8 ). 各症状について有効率をみた。くしゃみは治療 年数 3 年位までは $63 \% ， 4$ 年以上で $70 \%$ ～ $80 \%$ と上羊しし，長期治療が有効と思われた。

水性舅汁は, 減感作 1 年目で有効率 $35 \%$ 之他 の 2 症状に較べ低い值だが，治療年数と其に有

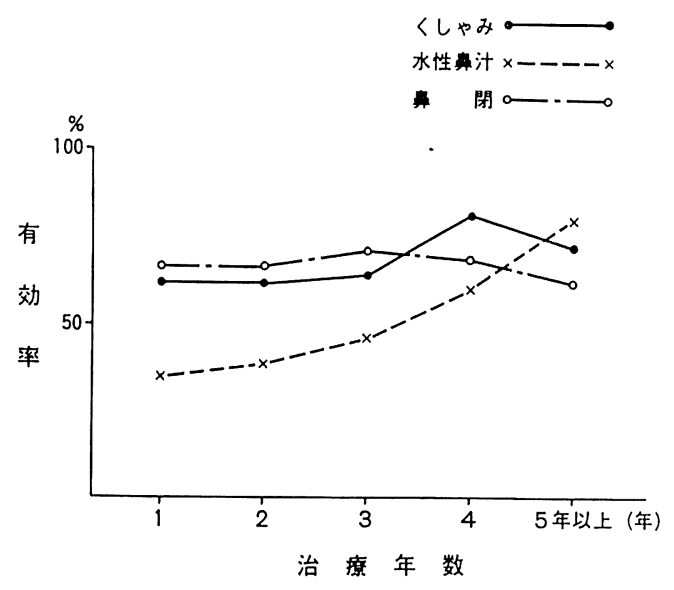

図 8 症状別有效率

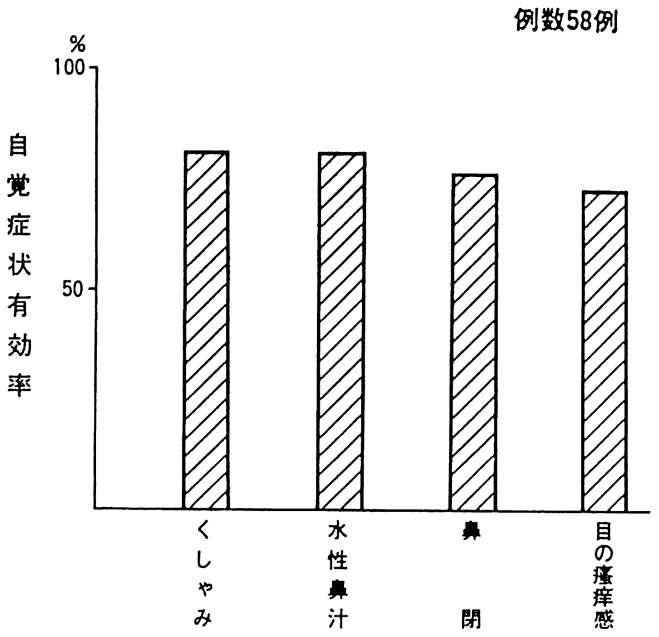

図 9 アンケート調相（自覚症状）

(1) 症状改善率
効率屯次第に上昇し，5年以上では $80 \%$ とな る。くしゃみ同様, 長期治療が有効と思われ る.

䋩閉は従来，減感作療法の效果が少ないと言 われているが，今回の調查では，平均65\%の有 効摔が認められた。

4 ) アンケート調查絬果 (図 9,10$)$.

139名に調查したが问答者は80名で回答摔は 57.6\%であった。

くしゃみ，水性鼻汒，鼻阙，目の瘙詳感の自 党症状改善率はくしゃみが $81 \%$ ，水性鼻汁 81 $\%$ ，鼻閉76\%で目の癌慞感の改善率は72\%であ った。

減感作㴊後での薬剂使用頻度については83\% から58\%と，25\%減少していた。

減感作治療己, 以前に受けた他の治療との比 洨では，月覚们に「減感俳治将の)かがよい」と

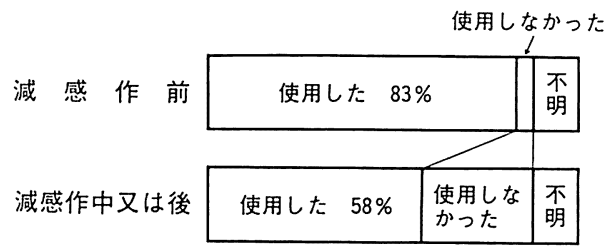

例数 60 例

図10 アンケート調查

(2) 薬剂使用頻度

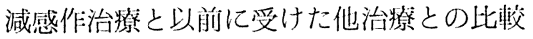

・減感作治獠がよい.............. $55 \%$

・他の治療の方がよい............ $0 \%$

• 同 じ........................... $3 \%$

・わからない........................ $42 \%$

例数 66例

減感作治撩を続けるかどうか

• 続けたい……….............64\%

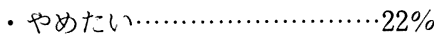

•わからない……................13\%

例数 67 例

図川アンケート調柤 
思っている患者は $55 \%$ ，「わからない」が42\% であった。

又, 減感作治療の継続を希車している患者は 64\%であった（図11）。

\section{考察}

花粉症に対する特暴的減感作療法を初めて行 ったのは Noom, L. と Freed, J. であるとさ 机ている ${ }^{8)}$. 以後, 減感作療法の有用性抢よび その効果の発現機序については今日まで様々な 人々により研究され, 効果についてはその有用 性がほぼ確立されている ${ }^{9)}$ が発現機序は依然明 確な答えは得られていない。しかしながら，動 物実験における兒疫学的な研筧より抗原特異的 なサプレッサーT細胞の誘賏の証明 ${ }^{10)}$ ，あるい はヒ卜鼻汁中の好塩基性細胞の数の減少9)など がその一機序として報告され, 徐々に明らかに されてきている.

今回, 我々は主にイネ科花粉症の特異的減感 作療法の有用性について臨床症状を中心に検討 を行った。

我国での花粉症に抢ける減感作療法について はスギ11)12)，イネ科12)，リンゴ13)，モモ ${ }^{14) な と ゙ ~}$ の報告がなされている。 スギに関しては一般に その成績は覀い。しかし, 藤田ら ${ }^{12)}$ はスギの抗 原の力価を高めるととにより，その治療効果が 上ったと報告している。リンゴ，モモ花粉症に おける減感作療法は70\%以上の効果が得られイ ネ科花粉症については小崎ら ${ }^{2)}$ は 2 年以上の減 感作施行例で著効, 有効, やや有効をあわせて 81\%の成績をあげている。

我々の治療成績む60\%以上の効果があり，減 感作療法を長期施行するほどその成績は向上し その有用性が確認された。

減感作治療に及ぼす因子のうち, 有効率に推 計学的差異が認められたのは, 男女別之䍜病期 閒別のそれぞれー部にであった。

男女別で女性の才が有効率がやや高いとと は, 高原ら ${ }^{15)} \mathrm{H} \mathrm{D}$ を含めた減感作治療成績で 述べているが，花粉症発症の性:着による櫂患率 および発症年齢の造いがある ${ }^{16}$ ことなどとあわ
せて兔疫学的な本療法に対する性差の効果発現 の䎭いがあることは興味のあるところである。

罹病期間別で 9 年以上の群が他の群より有効 率が有意に高かったととについては明らかでな い.

年秢別による減感作療法の効果については若 年者の方が治療効果がよいとする報告 ${ }^{17)}$ 之高䅷 者に有効率が高いとする報告 ${ }^{18)}$ がみられるが. 今回の我々の成縜では年柃による治療効果の差: 異はなかった。

減感作療法についての恁者に対するアンケー 卜調查では藤田ら ${ }^{12)}$ はスギ花粉症患者でその50 \%の人が減感作治療後は経渦良好と签え, 予悡 以上の高成績であったとしている。

我々のアンケート調查でも自覚㑏:状の改善率 が各症状とむ平均 $70 \%$ 以上とよい成績であっ た。しかしながら，治療継続を希耑しない， あ るいは継続するかどうか分らないと答えた患者 が36\%にみられた。その主な理由は治療効果が はっきりしない以外に仕事上時間が取れない， 徒ち時間が長いなど治療する側の改善努力を指 摘する声屯あり，減感作療法の成績向上には治 療内容とその期間扰よび治療効果についてよく 䑫明し，患者が治療を受けやすくするための努 力が必要と考えら机た。

\section{まとめ}

1）イネ科花粉症，114例に減感作治療を行 い遠隔成績を調査した。

2）イネ科抗原による特異的減感作潦法の䍀 休効果は65\% 85\%の有効率が認められ，長期 治療になるほどその成績は向上した。

3 ) 年齢別, 総 $\operatorname{IgE}$ 值別, 重複減感作別で は有効率の善がなかったが, 男女別では減感作 3 年目, 籊病期間別では 2 年目に有意差が認め られた。

4 ）くしゃみ, 水性鼻汁は長期治療に上り改 善傾向が大きく，鼻閘についても65\%の有効率 が得られた。

5 ）アンケート調査による自覚症状改善率は 平均75\%で, 減感作治療の有効性が確められ 
た。

本論文の要旨は第 4 回日本耳占咽堠科免疫アレルギ 一研究会で口演した。

\section{参考文献}

1) 矢島 洋, 他：イネ科花粉症における減感作治燎 成績. 日本鼻副鼾腔学会誌 $19: 36,1980$.

2) 小崎秀夫：イネ科牧草花粉症. アレルギーの臨床 $5: 2 ; 20 \sim 22,1985$.

3）信太隆夫，他：花粉症の研究. 第 1 報, 札棍市に おける牧草花粉症. アレルギー 17：97〜108, 1968.

4) 我妻義則, 他：花粉症の研究. 第 2 報, 札幌市に おける空中花粉飛散状況の検索成績. アレルギー $18: 56 \sim 69,1969$.

5 ）高坂知節，他：スギ花粉症の現状と治䝤. アレル ギーの臨休 $5: 2 ； 23 \sim 25,1985$.

6) 長野 準, 他：日本列島の空中花粉. 8〜 15頁, 北隆館, 東京, 1978 .

7) 奥田 稔: 舅アレルギー讋燎の实際. 183〜188 頁，金原出版，東京， 1979.

8）信太隆生：花粉アレルギー一基本療法一．136〜 147頁, 北隆館, 東京, 1979.

9) 奥田 稔： $\operatorname{IgE}$ アレルギー性舆炎と脱感作療法. 免疫薬理 $2 ： 242 \sim 249,1984$.
10) Tada $T$ : Regulation of reaginic antibody formation in animals. Prog Allergy 19 : 122 194, 1975.

11）清水章治：スギ花粉症に関する最近の研究. 北関 東医学 $32 ： 2 ； 85 \sim 92,1982$.

12）藤田洋鿆：スギ花粉症に対する減感作葲法. アレ ルギーの臨床 $10: 20 〜 25,1982$.

13）袷田 勝, 他：リンゴ花粉症における特異的減感 作療法。耳舅臨床 $76: 3159 \sim 3165,1983$.

14）清水章治, 他：モモ花粉症患者の長期減感作治獠 による臨床ならびに免疫学的検討.耳舅 29 ： 716〜720, 1983.

15）高原哲夫，他：参アレルギー減感作撩法の遠隔成 績. 日本楀副鼾腔学会誌 19:36３7，1980.

16）高橋光明, 他：前アレルギーの阽床一HD, Mite

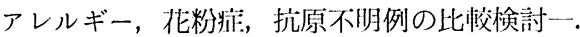
耳鼻臨床投稿中。

17) 打越 進, 他：各種臨床所芫による特罢们減感作

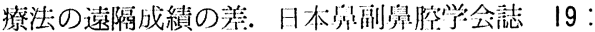
$39 \sim 40,1980$.

18）小関洋男，他：多アレルギーに対する減感作撩㑢 の長期成績一重症度別，年齢別にみた効果一。 H 本鼻副鼻腔学会誌 $20 ： 157 \sim 158,1981$.

\section{別们請求先：金関延幸}

T078 旭川市西神楽 4 線 5 号 $3-11$ 旭川哭科大学耳舅咽喉科学教室 